\title{
Sexual behavior patterns and HIV risks in bisexual men compared to exclusively heterosexual and homosexual men
}

\author{
José Antonio Izazola-Licea, MD, ScD, (1) Steven L Gortmaker, PhD, ,(2) Víctor de Gruttola, ScD, ${ }^{(3)}$ \\ Kathryn Tolbert, PhD, ${ }^{(4)}$ Jonathan Mann, MD, MPH. ${ }^{(5)}$
}

\begin{abstract}
Izazola-Licea JA, Gortmaker SL, GruttolaV,Tolbert K, Mann J. Sexual behavior patterns and HIV risks in bisexual men compared to exclusively heterosexual and homosexual men. Salud Publica Mex 2002;45 suppl 5:S662-S671. The English version of this paper is available too at: http://www.insp.mx/salud/index.html
\end{abstract}

\begin{abstract}
A bstract
Objective.To compare patterns of sexual behavior among bisexual, heterosexual and homosexual men. Material and Methods A household probability survey was carried out in Mexico C ity in 1992-1993 using the national health surveys sampling frame. Information from 8068 men was obtained; however, the main analysis of this paper refers only to men sexually active in the previous 5 years. Results. Bisexuals reported more prevalent anal intercourse with women $(16 \%$ vs. $3 \%, p=0.01)$, and more sexual encounters with female sex workers than exclusive heterosexuals $(10 \%$ vs. $4 \% ; p=0.04$ ). Bisexuals used condoms more often with sex workers than did heterosexuals $(p=0.01)$. Most of the bisexuals (79\%) did not engage in anal receptive or insertive intercourse with males in the previous year, practicing instead oral insertive sex or only masturbation; $35 \%$ of homosexuals did not report practicing anal sex. Bisexuals who engaged in anal intercourse had less anal receptive behavior than homosexuals ( $13 \%$ vs. $60 \%, p<0.01)$; of these, due to condom use, only $7 \%$ of bisexuals and $18 \%$ of homosexuals had unprotected anal receptive sex in the last intercourse with a male. Conclusions Bisexuals practice less risky sexual behavior with males than exclusive homosexuals. This finding may imply that bisexual men in Mexico
\end{abstract}

\author{
Izazola-Licea JA, Gortmaker SL, \\ Gruttola V,Tolbert K, Mann J. \\ Patrones de comportamiento sexual y de riesgo al VIH \\ en hombres bisexuales comparados con hombres \\ heterosexuales y homosexuales exclusivos. \\ Salud Publica Mex 2002;45 supl 5:S662-S671 \\ El texto completo en inglés de este artículo también \\ está disponible en: http://www.insp.mx/salud/index.html
}

\section{Resumen}

Objetivos. Comparar los patrones de comportamiento sexual entre hombres bisexuales, heterosexuales y homosexuales. Material y métodos Se llevó a cabo una encuesta probabilística en hogares de la Ciudad de México en 1992-1993, utilizando el marco muestral de las Encuestas $\mathrm{N}$ acionales de Salud; se obtuvo información de 8068 hombres entre 15 y 60 años de edad. El análisis principal de este trabajo se centra en hombres sexualmente activos en los cinco años previos a la encuesta. Resultados. Los hombres bisexuales notificaron con mayor frecuencia relaciones sexuales anales con mujeres ( $16 \%$ vs. $3 \%, p=0.01$ ), y mayor frecuencia de relaciones sexuales con trabajadoras sexuales que los heterosexuales exclusivos ( $10 \%$ vs. $4 \%, p=0.04)$. Los bisexuales usaron condones más frecuentemente con trabajadoras sexuales que los heterosexuales $(p=0.01)$. La mayoría de los bisexuales $(79 \%)$ no mantuvieron relaciones sexuales anales (receptivas 0 insertivas) con otros hombres en el año previo al estudio; en su lugar, llevaron a cabo sexo oral insertivo o sólo masturbación; $35 \%$ de los homosexuales exclusivos no reportó llevar a cabo ninguna práctica anal durante sus relaciones sexuales. Los bisexuales que mantuvieron coito anal tuvieron comportamientos receptivos con menor frecuencia

(1) Coordinación Ejecutiva de la Iniciativa Regional sobre SIDA para A mérica Latina y El Caribe.

(2) Department of Health and Social Behavior. Harvard School of Public Health.

(3) Department of Biostatistics. Harvard School of Public Health.

(4) Dirección del Programa Regional de Salud Reproductiva para América Latina.The Population Council, México.

(5) Department of Population and International Health. Harvard School of Public Health.

Received on:A pril 8, $1999 \cdot$ Accepted on: A pril 12, 2002

Address reprint requests to: MD, ScD. José A ntonio Izazola-Licea. Fundación Mexicana para la Salud. Avenida Periférico Sur 4809, Colonia El A renal Tepepan, D elegación Tlalpan 14610, México, DF, México e-mail: jizazola@ funsalud.org.mx 
are an ineffective epidemiological bridge for HIV transmission. The English version of this paper is available too at: http://www.insp.mx/salud/index.html

Key words: HIV; household survey; homosexuality; bisexuality; condom use; Mexico que los homosexuales exclusivos ( $13 \%$ vs. $60 \%$, p<0.01); de éstos, debido al uso de condón, sólo $7 \%$ de los bisexuales y $18 \%$ de los homosexuales tuvieron coito anal receptivo no protegido en la última relación sexual con otro hombre. Conclusiones. Los bisexuales mantuvieron comportamientos sexuales con otros hombres de menor riesgo que los homosexuales exclusivos. Este hallazgo podría implicar que los hombres bisexuales en México no son un puente epidemiológico efectivo para la transmisión delVIH . El texto completo en inglés de este artículo también está disponible en: http://ww w.insp.mx/salud/index.html

Palabras clave: VIH ; encuesta en hogares; homosexualidad; bisexualidad; uso de condón; México $\mathrm{n}$ the beginning of the AIDS epidemic, regional differences in the patterns of HIV transmission called attention to sexual diversity and cross-cultural differences in the patterns of sexual behavior. ${ }^{1,2}$ The AIDS epidemic rushed the scientific community to study human sexuality because of the need for accurate data on the incidence of HIV infection and the prevalence of different sexual behaviors linked to its transmission.

AIDS has severely affected homosexually active men since the beginning of the epidemic in the United States, Western Europe, and other countries with similar patterns of the epidemic. ${ }^{3}$

In Mexico, 20840 AIDS cases had been reported by the end of $1994 ; 85 \%$ were men. Of these, $95 \%$ were sexually acquired; $60 \%$ were homosexuals, $25 \%$ bisexuals, and $15 \%$ heterosexuals. Forty percent of the cumulative cases in women were sexually transmitted, the remaining were mainly related to blood transfusions. The information available, which was not routinely analyzed, pointed out that by the end of 1993, there were only 22 AIDS cases of newborns or infants whose father was reported to be bisexual, i.e., it was the risk factor for the mother becoming infected by HIV. HIV transmission due to intravenous drug use was almost negligible $\left(0.7 \%\right.$ of the cases). ${ }^{4}$ Findings of increased HIV seroprevalence and a low rate of condom use among behaviorally bisexual male blood donors support the hypothesis of bisexual behavior as a transmission mechanism of HIV infection to females. ${ }^{5-6}$ The lack of sufficient information and understanding of male bisexuality has led some researchers to assume that behaviorally bisexual men are at the same risk of contracting HIV as are exclusively homosexual men. In the study of HIV/AIDS dynamics, bisexuality is frequently treated as a subtype of homosexuality, and HIV infection in bisexual men is treated as part of the broader issue of homosexual transmission.

Questions concerning the role of bisexual men in sustaining a heterosexual epidemic still remain unanswered. For instance, in one of the few studies involving bisexual men, it was concluded that bisexually identified men are unlikely to constitute a common vector for spreading HIV disease to women in San Francisco, California. ${ }^{7}$

In previous communications, significant bisexual behavior has been reported among men interviewed in a cross-sectional convenience sample of gay gathering places in six Mexican cities. Also, one of the most significant risks for HIV infection in homosexually active men is to practice both insertive and receptive anal intercourse; the most plausible explanation of this increased risk resides in the social construction of the pool from which potential sexual partners are drawn, with whom such a mixed behavior can be practiced. . $^{-}$ ${ }^{10}$ We conducted this study of sexual behavior patterns (relevant to HIV transmission) in a representative population sample with low HIV transmission due to injection drug use, to assess the potential for HIV sexual transmission among bisexual men and their female sex partners.

\section{Material and Methods}

A household probability survey was carried out in the Mexico City metropolitan area (MCMA) from June 1992 to March 1993. A sampling frame from the National Health Surveys System of the Mexican Ministry of Health was used to conduct this survey. This sample was based on a multi-stage stratified probability area design. Eight thousand and sixty-eight non-institutionalized men between 15 and 60 years of age were 
interviewed from a total of 8759 eligible households. The participation rate (defined as the number of individuals who were successfully interviewed over those eligible) was $59 \%$, and the refusal rate $6 \%$. All men aged 15-60 years living in each household were considered eligible respondents ${ }^{11}$. A sub-sample of 6643 of those who were sexually active during the five years previous to the study was the basis for most of the data analysis.

Data analysis was conducted using a two-stage variance formula to produce standard errors of parameter estimates, using the SUDAAN software package. ${ }^{12}$. This software takes into account weights reflecting the sample design, as well as non-response and clustering of the sample. Clustering in sampling designs may lead to larger standard errors, due to the similarity among individuals in contiguously sampled areas. This loss of precision may be measured by the design effect, defined as "the multiplier to be applied to the variance of a survey estimate under simple random sampling to take account of the complex sample design"13. The design effects estimated for the sub-sample of homosexual and bisexual men were smaller than 1.3 for variables on sexual behavior. However, for variables reflecting socio-economic status (e.g. schooling and occupation), values were equal to four or greater. The $p$-values for cross-tabulations were calculated using a chi-squared test statistic analogous to the Pearson chi-squared test for non-survey data. However, when sample cross-tabulations had counts of five or less observations per cell, Fisher's exact test was performed.

Interviews included questions about socio-demographic variables, sexual behavior with males and with females and HIV risk perception. The questions on sexual behavior were asked according to three recall periods: lifetime, past five years, and past year; in addition, some variables were obtained for the last sexual intercourse that might have been referred to variable times of reference but that were thought to be more reliable than responses linked to periods of reference.

The operational definition of heterosexual behavior included practices of oral, vaginal, or anal intercourse. The operational definition of homosexual behavior included having engaged in oral or anal intercourse with a male, or physical contact with other men during masturbation. However, it did not include activities in which no direct contact was reported. The pattern of anal insertive or receptive behavior with other males was constructed from the number of male sexual partners with whom each of these practices was performed in the year prior to the interview.

\section{Results}

In Table I population estimates for the Mexico City metropolitan area men by gender of sexual partners in different periods of reference are presented, according to the sample distribution of respondents. An estimated $2.1 \%$ of men reported having male and female partners in their lifetime; $0.4 \%$ reported only male partners. Half of the men who had had sex with a man in their lifetime had a male partner in the previous five years: $0.8 \%$ had male and female partners, and $0.5 \%$ only male partners. Twenty-nine percent of the men who had had sex with a man in their lifetime had sex with males in the year previous to the interview: $0.3 \%$ with males and females and $0.5 \%$ only with males.

More than half (52\%) of the lifetime bisexual men had had only female partners in the previous five years, $40 \%$ continued having both male and female partners in that period, $5 \%$ were celibate, and the rest had had only male partners in the previous five years. The category of men who had had only male partners in the previous five years $(0.5 \%)$ was composed mainly of men who had been exclusively homosexual throughout their lives ( $80 \%$ of the total), and men who had had sex previously with women in their lifetime (bisexuals), but not during the previous five years.

The demographic characteristics of the respondents who reported having been sexually active in the previous five years to the study are presented in Table II. Those who reported having sex with other males in the previous five years were younger than exclusive heterosexuals. In addition, they had higher-level occupations (e.g., white collar vs. blue collar) and lived in their parents' household more frequently. As expected, men with exclusive heterosexual behavior were more frequently the head of the household, were married, and had children.

Men who had sex with both men and women in the reference period were less likely to be involved in stable relationships with women or with men when compared to exclusive heterosexuals or exclusive homosexuals. For example, while $81 \%$ of the exclusive heterosexual men were engaged in an on-going steady relationship with their last female sexual partner, only $45 \%$ of the bisexual men had a steady relationship with their last female sexual partner $(65 \%$ and $24 \%$ were married, respectively). Similarly, while $8 \%$ of the bisexual men had a steady relationship with their last male sexual partner, $34 \%$ of the exclusive homosexual men had their last sexual encounter with their stable male partners. 
Table I

\section{Population estimates and PeRcentage distribution by Gender of SEXUAL PARTNeRS} of men 15-60 Years old, Mexico City Metropolitan Area, 1992-1993

\begin{tabular}{lccccc} 
Gender of sexual partners & $\begin{array}{c}(\mathrm{N}) \\
\text { Unweighted }\end{array}$ & $\%$ & $(95 \% \mathrm{Cl})$ & $\begin{array}{c}\text { Population } \\
\text { Estimates }\end{array}$ & $(95 \% \mathrm{Cl})$ \\
$\begin{array}{l}\text { Lifetime partners } \\
\text { None }\end{array}$ & 1292 & 15.8 & $(13.0-18.6)$ & 470200 & $(387200-553200)$ \\
\hline All females & 6571 & 81.7 & $(68.9-94.3)$ & 2426500 & $(2049000-2804000)$ \\
\hline Males \& females & 173 & 2.1 & $(1.7-2.4)$ & 63700 & $(50100-70600)$ \\
\hline All males & 37 & 0.4 & $(0.3-0.6)$ & 12900 & $(7600-18200)$ \\
\hline Total & 8068 & 100 & 2973300 & &
\end{tabular}

\begin{tabular}{lrrrrr}
$\begin{array}{l}\text { Partners in past five years } \\
\text { N one }\end{array}$ & 1425 & 17.4 & $(14.4-20.4)$ & 517600 & $(428200-606600)$ \\
\hline All females & 6538 & 81.3 & $(68.7-93.9)$ & 2417700 & $(2043100-2792300)$ \\
\hline Males \& females & 66 & 0.8 & $(0.6-1.0)$ & 24000 & $(17300-30700)$ \\
\hline All males & 39 & 0.5 & $(0.3-0.7)$ & 14000 & $(8600-19400)$ \\
\hline Total & 8068 & 100 & 2973300 & &
\end{tabular}

\begin{tabular}{lrrrrr}
$\begin{array}{l}\text { Partners in past year } \\
\text { N one }\end{array}$ & 1978 & 22.6 & $(18.7-26.5)$ & 671700 & $(555200-788300)$ \\
\hline All females & 6029 & 76.7 & $(64.7-88.6)$ & 2279300 & $(1925000-2633600)$ \\
\hline Males \& females & 22 & 0.3 & $(0.1-0.4)$ & 8200 & $(4,100-12,300)$ \\
\hline All males & 39 & 0.5 & $(0.3-0.7)$ & 14000 & $(7700-20300)$ \\
\hline Total & 8068 & 100 & & 2973300 & $(2492000-3454500)$
\end{tabular}

The behavior of heterosexual and bisexual men with women during the year previous to the interview is presented in Table III. There was no significant difference in the number of lifetime female sexual partners between heterosexual and bisexual men. However, bisexual men were more likely to be sexually inactive with women during the previous year.

Bisexual men reported a higher frequency of relationships with female sex workers than heterosexuals $(10.4 \%$ vs. $3.4 \%$ respectively, $p=0.04)$. While the percentage of bisexual and heterosexual men who reported using a condom in all encounters with female sex workers in the previous year was $62 \%$, most of the remaining heterosexuals (35\%) reported not using a condom in any of those occasions, and all of the bisexuals $(38 \%)$ reported using a condom in half of the occasions or more frequently $(p=0.01)$.

A significantly higher prevalence of anal intercourse with the last female partner was found among bisexuals compared to heterosexuals ( $16 \%$ vs. $3 \%$, $p=0.01)$. There was only a marginally significant difference in the prevalence of condom use for this prac- tice between bisexual and heterosexual men; $61 \%$ vs. $25 \%$ respectively $(p=0.09)$.

Sexual behavior with males is presented in Table IV. Bisexual men reported fewer male sexual partners in their lifetime than homosexual men: $51 \%$ of the bisexual men and $25 \%$ of the homosexual men reported having had sex with only one or two men in their whole life, while $21 \%$ and $54 \%$ respectively, reported more than ten different male sexual partners.

While there was no difference in the number of partners with whom the respondent performed anal insertive intercourse in the past year, a marked difference was found between bisexuals and homosexuals in the number of sexual partners with whom they had anal receptive sex $(13 \%$ vs. $60 \%, p<0.01)$.

Differences in rates of oral insertive sex $(63 \%$ vs. $36 \%$ between bisexuals and homosexuals respectively) were only marginally significant ( $p$-value 0.06 ).

The pattern of insertive-receptive behavior with male partners in the past year was remarkably different between homosexual and bisexual males (Figure 1). 
Table II

SOCIODEMOGRAPHIC AND PARTNERSHIP STATUS CHARACTERISTICS ACCORDING TO THE GENDER OF SEXUAL PARTNERS IN THE PREVIOUS FIVE YEARS.* Mexico City Metropolitan Area, 1992-1993

\begin{tabular}{ccccc}
\multicolumn{4}{c}{ Gender of sexual partners } \\
in previous five years & & \\
\cline { 2 - 2 } & Males \& & All & \\
females & females & males & \\
$(n=6538)$ & $(n=66)$ & $(n=39)$ & \\
$\%$ & $\%$ & $\%$ & p-value
\end{tabular}

Age

\begin{tabular}{lllll}
$15-19$ & 10 & 24 & 24 & $<0.0001$ \\
\hline $20-29$ & 36 & 56 & 46 & \\
\hline $30+$ & 54 & 20 & 30 &
\end{tabular}

Education

\begin{tabular}{lllll} 
Primary or less & 25 & 22 & 16 & N.S. \\
\hline Secondary high school & 50 & 57 & 59 & \\
\hline College or more & 25 & 21 & 25 &
\end{tabular}

O ccupation

\begin{tabular}{lrrrr} 
Blue collar & 18 & 9 & 12 & 0.001 \\
\hline Medium/student & 42 & 39 & 52 & \\
\hline W hite collar \& professionals & 36 & 43 & 29 &
\end{tabular}

Position in the household

\begin{tabular}{lllll} 
Head & 61 & 29 & 15 & $<0.0001$ \\
\hline Son & 29 & 53 & 57 & \\
\hline O ther & 10 & 18 & 29 &
\end{tabular}

Marital status

\begin{tabular}{lllll} 
Single/divorced/widowed & 35 & 76 & 95 & $<0.0001$ \\
\hline Married/common law & 65 & 24 & $5^{1}$ & \\
\hline Had children & 63 & 19 & 3 & $<0.0001$
\end{tabular}

Had a stable relationship with

\begin{tabular}{lrrrrr} 
Last female sexual partner & 81 & 45 & - & 0.0001 \\
\hline Had a stable male partner & - & 9 & 32 & 0.03
\end{tabular}

Had a stable relationship with

$\begin{array}{llllll}\text { Last male sexual partner } & - & 8 & 34 & 0.03\end{array}$

* This figure includes individuals who reported being married but who had had only male sexual partners in the previous five years

Thirty-five percent of exclusively homosexual men did not practice insertive or receptive anal intercourse. Five-percent practiced only insertive behavior. Receptive anal behavior was practiced as an exclusive behavior by $33 \%$ of homosexual men. Twenty-seven
Table III

Heterosexual practices and condom use in the LAST SEXUAL INTERCOURSE AND NUMBER OF SEXUAL PARTNERS ACCORDING TO THE GENDER OF SEXUAL PARTNERS IN THE PREVIOUS FIVE YEARS IN A HOUSEHOLD probability survey in Mexico City Metropolitan AREA, 1992-1993

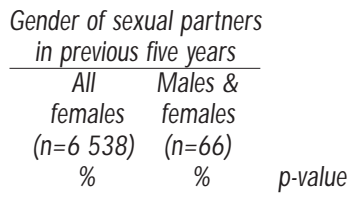

Lifetime N 0. of female partners

\begin{tabular}{llll}
$1-2$ & 29 & 23 & N.S. \\
\hline $3-9$ & 45 & 51 & \\
\hline $10+$ & 26 & 27
\end{tabular}

Previous year $\mathrm{N}$ o. of female partners

\begin{tabular}{lrrr} 
None & 7 & 26 & $<0.0001$ \\
\hline $1-2$ & 84 & 54 & \\
\hline $3-9$ & 9 & 17 & \\
\hline $10+$ & 1 & 3 &
\end{tabular}

N 0. of female sex workers in previous year

\begin{tabular}{lrrr} 
None & 96 & 90 & 0.04 \\
\hline $1-2$ & 3 & 10 & \\
\hline $3+$ & 1 & 0 &
\end{tabular}

Condom use with female

Sex workers in past yeaR*

\begin{tabular}{lrrr} 
N ever & 35 & 0 & 0.01 \\
\hline Half of the times or more & 3 & 38 & \\
\hline Always & 62 & 62 &
\end{tabular}

Behavior in last sexual encounter

\begin{tabular}{lrrr} 
Vaginal Intercourse & 99 & 97 & N.S. \\
\hline Condom use in vaginal intercourse* $^{20}$ & 25 & N.S. \\
\hline Anal intercourse & 3 & 16 & 0.01 \\
\hline Condom use in anal intercourse $^{1}$ & 25 & 61 & 0.09
\end{tabular}

* Condom use among those who practiced the behaviors in last sexual intercourse

percent practiced mixed behavior (both insertive and receptive anal intercourse).

Seventy-nine percent of bisexual men did not engage in anal insertive or anal receptive intercourse with any man in the year previous to the interview; $7 \%$ were only insertive. Fourteen percent performed mixed practices. No bisexuals reported receptive intercourse ex- 


\section{Table IV \\ HomoseXUAL PRACTICES AND CONDOM USE IN THE LAST SEXUAL INTERCOURSE AND NUMBER OF SEXUAL PARTNERS ACCORDING TO THE GENDER OF SEXUAL PARTNERS IN THE PREVIOUS FIVE YEARS in a household probability SURVey IN MeXico City Metropolitan Area, 1992-1993}

\begin{tabular}{|c|c|}
\hline $\begin{array}{l}\text { Gender of se } \\
\text { in previou }\end{array}$ & $\begin{array}{l}\text { al partners } \\
\text { ive years }\end{array}$ \\
\hline $\begin{array}{l}\text { Males \& } \\
\text { females } \\
(n=66)\end{array}$ & $\begin{array}{c}\text { All } \\
\text { males } \\
(n=39)\end{array}$ \\
\hline$\%$ & $\%$ \\
\hline
\end{tabular}

Lifetime male partners

\begin{tabular}{llll}
$1-2$ & 51 & 25 & 0.003 \\
\hline $3-9$ & 28 & 21 & \\
\hline $10+$ & 21 & 54 &
\end{tabular}

N umber of anal receptive partners

in Past year (respondent was insertive)

\begin{tabular}{lrrr} 
None & 79 & 70 & N.S. \\
\hline $1-2$ & 13 & 17 & \\
\hline $3-9$ & 3 & 8 & \\
\hline $10+$ & 6 & 5
\end{tabular}

N umber of anal Insertive partners

in past year (respondent was receptive)

\begin{tabular}{lrrr} 
None & 86 & 41 & $<0.0001$ \\
\hline $1-2$ & 10 & 34 & \\
\hline $3-9$ & 3 & 7 & \\
\hline $10+$ & 1 & 18 &
\end{tabular}

Behavior in last sexual encounter

\begin{tabular}{|c|c|c|c|}
\hline Oral insertive & 63 & 36 & 0.06 \\
\hline Condom use for oral insertive ${ }^{1}$ & 12 & 14 & N.S. \\
\hline O ral receptive & 16 & 48 & 0.02 \\
\hline Condom use for oral receptive ${ }^{1}$ & 24 & 15 & N.S. \\
\hline \multicolumn{4}{|l|}{ Sex with other men without } \\
\hline Engaging in anal intercourse & 66 & 33 & 0.02 \\
\hline Anal insertive intercourse & 33 & 25 & N.S. \\
\hline Condom use for anal insertive ${ }^{1}$ & 20 & 74 & N.S. \\
\hline Anal receptive intercourse & 13 & 60 & $<0.01$ \\
\hline Condom use for anal receptive ${ }^{1}$ & 52 & 71 & N.S. \\
\hline Paid to have sex & 3 & 3 & N.S. \\
\hline \multicolumn{4}{|l|}{ Condom use when respondent paid } \\
\hline to have Sex ${ }^{1}$ & 100 & 100 & N.S. \\
\hline Received payment to have Sex & 15 & 7 & N.S. \\
\hline \multicolumn{4}{|c|}{ Condom used when respondent was } \\
\hline paid for Sex ${ }^{1}$ & 10 & 63 & N.S. \\
\hline
\end{tabular}

clusively or as the most frequently practiced behavior (Figure 1). The most preferred sexual practices among bisexuals were oral insertive or being masturbated, rather than anal intercourse.

The pattern of behavior practiced in the last sexual encounter with a male partner showed significant differences in the frequency of oral and anal receptive behaviors, as well as in the proportion of men having sex with other men but not engaging in insertive or receptive anal intercourse in bisexual and homosexual men.

Three percent of the respondents had a paid last sexual intercourse with a male; all used a condom during that relationship. Fifteen-percent of bisexual men and $7 \%$ of homosexual men received payment (in-cash or in-kind) in order to have their last sexual intercourse with a man $(p>0.10)$.

There were no significant differences in the frequency of condom use between exclusively homosexual and bisexual men, neither by sexual practice nor involvement of payment in the last sexual encounter with a male.

The majority of respondents (56\%) of the total of behaviorally bisexual males during the 12 months previous to the interview $(n=27)$, reported having used condoms with their male or female partners; however, $44 \%$ informed not doing so with neither of flum. Only $22 \%$ of these men reported use of condoms with both male and female partners.

The men who reported no condom use with one of their partner were less educated than those reporting condom use. Only one of these 12 men reported having used a condom ever.

This subsample was evenly split on men with low risk behaviors for STI's/HIV, and the other half reported multiple female partners (more than 10 lifetime),

Table V

\section{Condom USE DURING LAST SEXUAL VAGINAL INTERCOURSE BY MALES WHO HAD SEX WITH OTHER MALES IN THE PAST YEAR. Mexico City Metropolitan Area, 1992-1993}

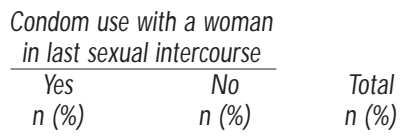

Condom use with other men in last 12 months

\begin{tabular}{lrrr} 
Always/ almost always & $6(22.2)$ & $5(18.5)$ & $11(40.7)$ \\
\hline N ever & $4(14.8)$ & $12(44.4)$ & $16(59.2)$ \\
Total & $10(37.0)$ & $17(62.9)$ & $27(100)$
\end{tabular}



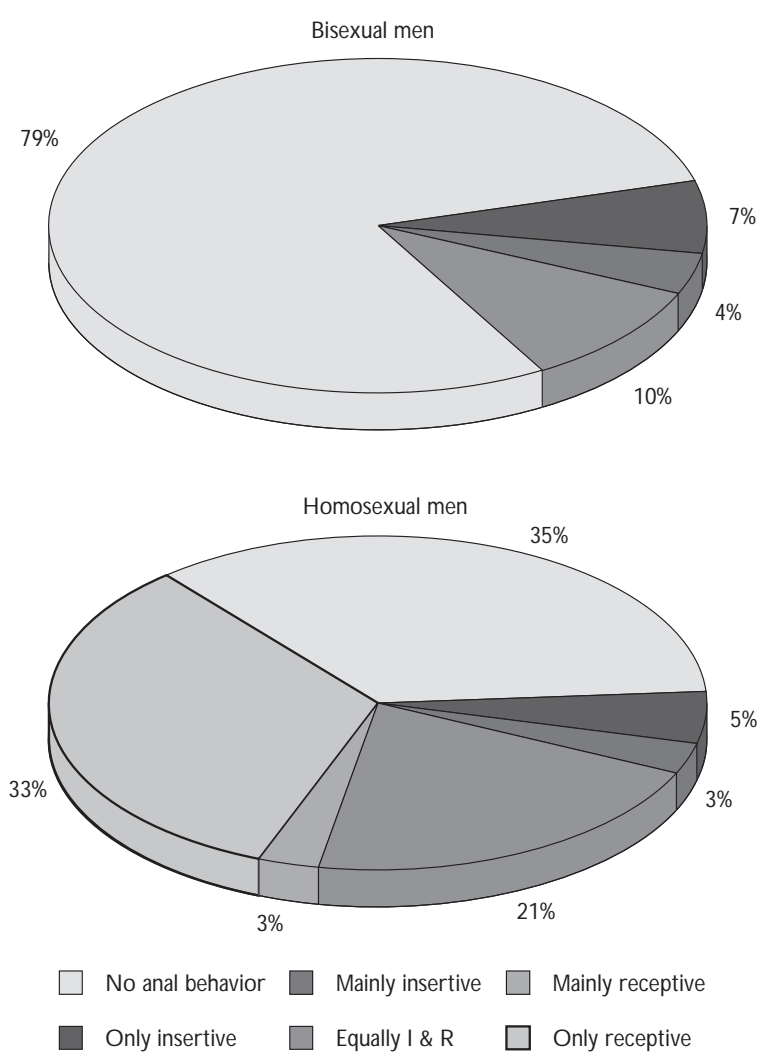

Figure 1. Patterns of anal insertive-Receptive behaVIOR IN BISEXUAL AND hOMOSEXUAL MEN IN MEXICO CITY, 1992-1993

history of STI's, no stable partnership relationship with women, of those having stable female partners having extra-relational partners.

Of their activities with other men, only five of the 12 men reported insertive anal sex in the previous year; only one reported being anal receptive in the previous year, only other one reported having been penetrated in his lifetime (both less than a dozen times in their lifetime). Nine of the 12 reported less than five male lifetime sex partners; only one reported a current stable male partner. Only one subject reported more than 200 lifetime sex partners; he was also the only one reporting having performed oral sex to other men; while 10 of the 12 performed oral insertive roles with their male partners. Only one reported sex with female commercial sex workers and none of them paid for sex with men; however, one reported having received payment for having sex with his last male partner.
The place in which the sexual encounters occurred was in the home of either one in seven of the 12 cases and in public places (cars, saunas) in the remaining five.

These 12 men were more responsive to being asked to have sex with men, since nine of the 12 were asked to do so, while 10 of the 12 asked their female sex partners to have sex with them.

Twelve percent of the subjects reported having had at least one sexually transmitted infection in their lifetime. There were statistically significant differences in the frequency of these lifetime reports: $23 \%$ for homosexual men, $23 \%$ for bisexuals, and $12 \%$ for heterosexuals $(p=0.001)$. Exclusively homosexual men reported a higher number of episodes in their lifetime than bisexuals: $10 \%$ of homosexual men reported two or more STIs, compared to $3 \%$ of bisexual men. The frequency of two or more infectious episodes in the previous year was significantly higher in bisexual males $(11 \%)$, than in homosexual $(3 \%)$, and heterosexual men $(1 \%$, $p$-value $<0.0001)$.

Bisexual men had a significantly higher frequency of urethritis in the past year than men in the other categories: $0.3 \%, 4.7 \%$, and $0.0 \%$ for heterosexual, bisexual, and homosexual men, respectively ( $p=0.001$ ). Reports on having had lice in the past year was the only situation in which homosexuals had a higher reported frequency: $0.2 \%, 1.4 \%$, and $2.5 \%$ for heterosexuals, bisexuals, and homosexuals, respectively.

The population estimate of sexually active males in the Mexico City Metropolitan Area who had a STI in the year previous to the interview was 27,684 (95\% CI: 19,174-36,194).

The perceived risk for acquiring HIV due to previous sexual behavior was assessed differently for homosexual, bisexual, and heterosexual men: $66 \%, 26 \%$, and $37 \%$ respectively, reported they were not at risk for HIV due to their previous sexual behavior; $6 \%, 17 \%$, and $27 \%$ of heterosexuals, bisexuals, and homosexuals, respectively, perceived their past HIV-risk as high.

Most of the sample did not perceive themselves to be at risk for HIV because of their current sexual behavior: $89 \%, 66 \%$, and $71 \%$ of heterosexual, bisexual and homosexual men respectively, while only a minority thought they were currently at high risk for HIV: $1 \%$ of heterosexuals, $12 \%$ of bisexuals, and $4 \%$ of homosexuals.

The majority of the respondents had not been tested for HIV: $88 \%$ of heterosexuals, $79 \%$ of bisexuals, and $51 \%$ of homosexuals. Of those already tested for HIV, $60 \%$ of the heterosexuals, $33 \%$ of the bisexuals, 
and $27 \%$ of the homosexual men had been tested only once.

When behaviorally defined bisexual men were asked about their sexual identity, 73\% said they were heterosexual, $13 \%$ bisexual, $13 \%$ homosexual, and $1 \%$ did not know. Twenty nine per cent of the exclusively homosexual indicated they were heterosexual, $5 \%$ bisexual, and $66 \%$ homosexual. Only $0.5 \%$ of behaviorally heterosexual men did not report their identity as heterosexual.

Disclosure of respondents' homosexual behaviors with friends was reported by $60 \%$ of exclusively homosexual men and by $27 \%$ of bisexual men $(p<0.0001)$. Only $18 \%$ of the bisexuals who had an ongoing steady relationship with a female informed her of their homosexual behavior.

\section{Discussion}

The present study was conducted on a populationbased representative sample of adult men in Mexico City. The patterns of sexual behavior involving risks for HIV transmission were described according to the gender of sexual partners during the previous five years.

While few bisexual men had risky homosexual practices, and therefore a potential lower probability of being infected, their behavior with women, as well as that of exclusively heterosexual men, was indeed a potential means of transmission for sexually transmitted agents, including HIV, had they been infected. Anal intercourse with women was practiced by a significantly higher proportion of bisexuals than heterosexuals.

Regarding their sexual behavior with males, bisexuals reported significantly fewer male lifetime partners, and fewer partners in the previous year compared to exclusive homosexuals. Anal intercourse was practiced less frequently by bisexuals compared to homosexuals, and among those bisexuals who practiced anal behavior, the preferred practice was anal insertive, which may have a lower risk for acquisition of HIV ${ }^{14}$ Unfortunately, condoms were used only by one-third of the bisexuals while being insertive and by half of them while being anal receptive.

As the frequency of lifetime sexually transmitted diseases was similar for homosexual and bisexual men $(23 \%)$, homosexuals reported a higher number of episodes than bisexuals. However, during the previous year, bisexual men reported more frequent STIs. Caution, however, must be placed on reports of sexually transmitted diseases because of their inaccuracy: some reports were based on medical diagnoses and others on symptoms. The low frequency of reports of an STI in the past year and the small size of the population of bisexual and homosexual men could have resulted in a lack of statistical power to detect significant differences in the reports of STI by sexual orientation. In reports from a general population survey in the United States, the prevalence estimate for reported lifetime sexually transmitted diseases was $16 \%$, and $1.5 \%$ in the previous year ${ }^{15}$ (these estimates are not statistically significantly different from the estimates in this study).

Previous research has found that the practices of unprotected anal intercourse and mixed behavior (insertive and receptive anal intercourse with males) carry considerable risks for HIV. This study shows that there were differences in the practice of insertive and receptive anal intercourse by sexual practice during the last year: $35 \%$ of homosexuals and $79 \%$ of bisexuals reported no anal sex.

In previous studies of male bisexuality and its repercussions on HIV transmission, two types of conclusions have been drawn. First, some studies have concluded that behaviorally bisexual men are an efficient conduit between the homosexual male and the female population, even when most of these studies have found a lower HIV risk in bisexual men than in homosexual men. The lack of self identification as bisexuals, even if individuals have sex with men and women, and a consequent lack of risk perception is thought to hinder the adoption of safer sex practices. ${ }^{16}$ A second type of conclusion was drawn from a study in San Francisco, California, in self-identified bisexual men: even when some individuals were infected through homosexual practices and transmitted HIV to their female partners, profound changes in bisexually identified men significantly lowered the practice of risky behavior with women and men. This change occurred both as a personal risk reduction and as protection for their sexual partners.

Sexual orientation has been defined as the "erotic and/or affectional disposition to the same and/or opposite sex"17. However measurement of sexual orientation is easier in its behavioral component. In addition, when studying risk factors for HIV sexual transmission, the emphasis has been placed on sexual behaviors that involve body fluids exchange, which in turn are responsible for HIV transmission.

Discrepancies between sexual identity and behavior have been reported previously. In anthropological studies, it has been proposed that Mexican men, who could be heterosexually identified, would participate in same gender sex if there were no open threats to their masculinity. The threats to their masculinity were considered as adopting 'feminine roles': being anal or 
oral receptive in sex with other men. ${ }^{18}$ In the same way that insertive behaviors are preferred to receptive behaviors, oral insertive behaviors would be preferred over anal insertive practices among behavioral bisexuals who do not have a same-gender-sex identity.

Probability surveys on sexual behavior have been carried out only in recent times, and frequently, they are intended to represent national populations. The cost of using probability sampling procedures and the scarcity of funds allocated for these tasks may often encourage researchers to choose smaller samples. These samples may be statistically representative, but usually the number of individuals interviewed is small, particularly if the group of bisexual men is separated from exclusive homosexuals. Even when the results are based on a small number of sample individuals, because of the low prevalence of bisexual behavior in population-based samples, the probability sampling methodology assures that inference to a larger population be made. However, the major problem arises when conducting statistical analysis, which in general would have a low statistical power to test for significant differences.

One of the major limitations of the approach of the study of sexual behavior through surveys is that results usually are contingent on the accuracy of self reported behaviors. In a previous communication, a significantly higher prevalence of HIV was found among individuals who reported same gender sexual behavior in this sample. ${ }^{11}$

The fact that small design effects were found regarding variables of sexual behavior, may imply that most of the people who engage in different patterns of sexual behaviors do not cluster by place of residence. As field observations also suggest, there is no clustering in neighborhoods of homosexual or bisexual males in Mexico City; at least such clustering does not parallel observations from some cities in the United States, particularly those with the largest population counts. In addition, no difference was found in the prevalence of Same Gender Sexual Behavior (SGSB) according to the time of residence in Mexico City. Therefore there is no indication that homosexual and bisexual men migrated to Mexico City because of their sexual behavior.

The findings of this study need to be compared and validated with other representative samples of Spanish-speaking men in Latin-America and in the United States, since Hispanics or Latinos in the US, unless well acculturated, would likely reflect sexual practices from their countries of origin, and the adoption of sexual roles may be different in comparison to men from other cultures. ${ }^{19}$ However, other important variables should be taken into account when comparing these populations; for instance, HIV heterosexual transmission may be confounded by the use of injection drugs and the sharing of needles and syringes.

The findings of this study suggest that the prevalence of same-gender sex is low for both exclusive homosexual and bisexual behaviors, and that bisexual behavior is more common than exclusive homosexual practices. Even when some bisexual men have a high risk of acquiring HIV because of their unprotected behavior with other men, most of the behavioral bisexual men in the Mexico City community had a much lower risk because of fewer male partners and the avoidance of anal intercourse, particularly the avoidance of receptive anal intercourse, and condom use. Under this scenario, bisexual men do not appear to have a high prevalence of HIV as a group, and they may not be an effective epidemiological bridge for HIV transmission. A slower growth of the HIV/AIDS epidemic in women and newborns could be expected in Mexico City due to the lack of a large population of active bisexual men who engage in risky sexual behavior, who are currently infected or at high risk to acquire HIV.

\section{References}

1. Mann J, C hin J, Piot P, Q uinn T.The International Epidemiology of AIDS. Scientific American, 1988;259:82-89.

2.Valdespino JL, Izazola-Licea JA, Rico B.AIDS in Mexico:Trends and projections. Bull Pan Am Health O rgan 1989;23:20-23.

3. Mann JM, Tarantola DJM, N etter TW, ed. AID S in the world. A global report. Part I: C hapters 2 and 3. Cambridge, MA: H arvard U niversity

Press, 1992.

4. Secretaría de Salud. México. Boletín Mensual SIDA/ETS. Secretaría de Salud, México, D.F., 1995;13:1-15.

5.Tielman RAP, C arballo M, Hendriks AC, ed. Bisexuality and AIDS.A global perspective. Prometeus Books, Buffalo, N Y: 1991.

6. Wood RW, Krueger LE, Pearlman TC, Goldbaum G. HIV transmission: women's risk from bisexual men. American Journal of Public Health, 1993:83:1757-1759.

7. Ekstrand ML, C oates TJ, G uydish JR, Hauck W W, Collette L, Hulley SB. Are bisexually identified men in San Francisco a common vector for spreading HIV infection to women? Am J Public Health 1994;84: 915-919.

8. Trichopoulos D, Sparos L, Petridou E. Homosexual role separation and spread of AIDS. (Letter). Lancet 1988;2:965-966.

9. Izazola-Licea JA,Valdespino-Gómez JL, Gortmaker SL,Towsend J, Becker J, Palacios-Martínez M et al. HIV-1 seropositivity and behavioral and sociological risks among homosexual and bisexual men in six Mexican cities. Acquir Immune D efyc Syndr. 1991;4: 614-622.

10. Hernández M, U ribe P, G ortmaker S,Avila C, De C aso LE, Mueller N et al. Sexual behavior and status for human immunodeficiency virus type 1 among homosexual and bisexual males in Mexico City. Am J Epidemiol 1992;135:883-894. 
11. Izazola-Licea JA, G ortmaker S, De G ruttola V,Tolbert K, Mann J. Assessment of non-response bias in a probability household survey of male same-gender sexual behavior. Salud Publica Mex 2000; 42:90-98.

12. Research Triangle Institute. Software for survey data analysis (SUDAAN) version 5.31. Research Triangle Park, N C:1990. 13. Kalton, G. Sampling considerations in research on HIV risk and illness. En: Methodological issues in AIDS behavioral research, ed. D avid G. 0 strow, Ronald C. Kessler. Plenum Press, N ew York: 1993.

14. Kingsley LA, D etels R, Kaslow R, Polk BF, Rinaldo CR Jr, Chmiel J et al. Risk factors for seroconversion to human immunodeficiency virus among male homosexuals: Results from the multicenter AIDS cohort study. Lancet 1987;1:345-349.

15. Laumann EO, Gagnon JH, Michael RT, Michaels S.The social organization of sexuality. Sexual practices in the United States. University of Chicago Press: C hicago, 1994.
16. D oll LS, Petersen LR, W hite CR, Johnson ES,W ard JW and The Blood Donor Study Group. Homosexually and non-homosexually identified men who have sex with men:A behavioral comparison. J Sex Res. 1992;29:1-14.

17. Shively MG, De Cecco JP. Components of sexual identity.J Homosex, 1977;3:41-48.

18. Bell A, W einberg M. Homosexualities:A study of diversity among men and women. N ew York: Simon \& Schuster, 1978.

19. Carrier J. Mexican male bisexuality. En: Bisexualities. Theory and Research. F. Klein and J.W orlf, eds. N ew York: Haworth Press, 1985: 75-85. 